\title{
Land Fragmentation and Crop Production in Gwer-West Local Government Area of Benue State, Nigeria
}

\author{
Dr. Terwase Shabu, Ornyar Amos Gari and Mfanyo Keziah Ukula \\ Department of Geography, Benue State University, Makurdi
}

\begin{abstract}
Land fragmentation has been a global question as to what impact it represents on modern agriculture in general and crop production in particular from different societies due to declining output with increasing need for more input (cost). This study is aimed at assessing the impact of land fragmentation on crop production in Gwer-West Local Government Area with certain target to determine the dynamic nature of farm sizes, examine the factors responsible and give analysis of impact inherent in such dynamics as well as suggesting possible remedies to that effect. A sample size of 398 respondents was used. The study employed multistage random sampling technique starting from the study areas two major divisions to its four area development offices from which one ward each was selected except Gaambe/Sengev where two were taken. Simple random technique was used to make choices of specific farms for close observation while the systematic random technique was used in selecting respondents. Data on farm sizes, factors of land fragmentation and its impact on crops, crop yield, input per unit of land. Data analysed using frequency distribution tables, percentages and presented on graphs/charts. Results show that, 20 years ago $59 \%$ of farmers were having 10 ha and above as their total land stock whereas only $33 \%$ of the farmers presently have 10 ha and above. The result also shows that 20 years ago, $33 \%$ of the farmers in the area had between $1-2$ ha where as $72 \%$ of the farmers currently have between $1-2$ ha farm size. the analysis reveal that, majority of the farmers were producing between $11-15$ bags $(100 \mathrm{~kg}) 20$ years ago whereas, only $27 \%$ of the farmers in the area produce between 11-15bags $(100 \mathrm{~kg})$. Also, agricultural land use has changed from rotational bus fallowing to intensive farming. The major causes of land fragmentation in the area include: land ownership through inheritance and rapid population increase. The study concludes that land fragmentation has negative impact on crop production-crop productivity and agricultural activities. The paper therefore recommends land consolidation measure, population control and change in land reforms in order to reduce land fragmentation in the area.
\end{abstract}

Keywords: land fragmentation, crop production, land consolidation, population growth, land ownership

DOI: $10.7176 / \mathrm{JAAS} / 64-03$

Publication date:May $31^{\text {st }} 2020$

\section{INTRODUCTION}

The nature of land fragmentation is understood and defined differently within various economic and social contexts as a result, several approaches and methods have been developed and used to analyse the phenomenon. The lack of a conventionally consensus approach has led to the emergence of opposing views and conclusions about whether land fragmentation should be conceived as a problem or not (Demetriou, 2013). The varied multidisciplinary conception, treatment and measurement of this phenomenon has resulted to what can be termed a "contested causation" which has seen persistent radical scientific disagreement, a bone that has attracted several researchers leading to series of debates. The renewed concern is as a result of declining agricultural productivity, farm inefficiency and persistent food insecurity in developing countries of the world.

Land fragmentation is defined as a situation in which a single farm consists of numerous spatially separated parcels (van Dijk, 2003; Demetriou, 2013). This means that at any point that a farming household owns or possesses several non-contiguous land plots, often scattered over a wide spatial extent, fragmentation has occurred. Blarel, Hazell, Place \& Quiggin (1992) put the nature of land fragmentation in Sub-Saharan Africa as a situation where a household operates more than one separate parcel of land. This definition however, does not capture the nature of existing land fragmentation in the region today. According to Melmed-Sanjak, Bloch, \& Hanson (1998) "it is a phenomenon of agricultural land distribution in undersized holdings as well as holdings that consist of noncontiguous and spatially dispersed plots of land". Van Dijk (2003), distinguishes four dimensions of defining land fragmentation: fragmentation in ownership; number of users (or size of use units); internal fragmentation and fragmentation due to overlap of ownership and use. The major concern in the Sub-Saharan Africa today is the declining farm size in both ownership and use which logically implies diseconomies of scale in food production.

The phenomenon land fragmentation is a pervasive one in many agricultural societies especially among developing and transitional economies of the world. There has always been a seeming controversy among scholars, agriculturist and other interested parties bordering on what exactly the term "land fragmentation" entails. This however sterns from the factual evidence that the term or phenomenon lacks a universally accepted definition and therefore, has been left susceptible to a multi-fold of meanings ascribed it by different stakeholders/parties in the science and practice of agriculture from various spatial, temporal and professional climes.

In simple and non-detailed terms, many people conceive this phenomenon as a manifestation of spatial 
dispersion and non-connectivity in farmland ownership or possession. In their submission, Dovring etal (1960) in an analysis of land reform in Europe as cited in Mcpherson (1982) regarded land fragmentation as the division of land into a great number of distinct plots. They pointed out that the French used two concepts for land fragmentation in their consolidation operation which include Îlot de propriete and plotle. The former referred to a piece of land owned by a single person and surrounded by the property of others. The latter was a plot located apart from the Îlot de propriete. Land fragmentation meant that farmers owned plotles which did not form part of their Îlot de propriete.

The discussion about the problem of land fragmentation began in 1826 with the publication of Johan Von Thunen's titled "The isolated state" (Bentley, 1987). Von Thunen's basic thought was the simple statement that "costs of farming increase with distance". Particularly, when parcels are spatially dispersed, then travelling time and hence costs in moving labour, machines and othe factors from one parcel to another are increased (Abawua and Shabu, 2014) thereby emphasising the role of distance in fragmentation. Bentley noted that land fragmentation means a holding consisting of several scattered plots over a wide area. Brabec, Smith, (2002) saw land fragmentation as a stage in the evolution of the agricultural holding in which a single farm consists of numerous discrete plots, often scattered over a wide area. According to him, land fragmentation represents a stage in the agricultural holding's evolution. This suggests that if the holding is evolving towards consolidation, land fragmentation may be a temporary phenomenon.

Tan, Heerink, Qu, (2006) defined land fragmentation as a decrease in the average size of farm holdings; and increase in the scattering of each farmer's land; and a decrease in the size of the individual plots in a farm holding. Generally, even though land fragmentation is understood and defined in different ways, according to Karangwa (2010) in his M.Sc dissertation, three distinct interpretations can be identified:

(i) it implies the subdivision of farm property into undersized units that are too small for rational cultivation; (ii) it suggests that the plots are non-contiguous and are intermixed with plots operated by other farmers;

(iii) the last type sees distance as an important aspect of land fragmentation.

Identifying the root cause of land fragmentation is key to understanding the long-term effects of the prevalence of the phenomenon in Sub-Saharan Africa (Demetriou, 2013). Land tenure is the principal factor influencing fragmentation in Sub-Saharan Africa. It is common knowledge that most societies in Sub-Saharan Africa practice the culture of patrilineal succession and inheritance where properties, land inclusive are successively shared among lineages, to families and again to individuals as it is their right of inheritance. The individual's land is further shared equally among the male children of an individual parent (Holden and Mace, 2003). Inheritance laws facilitate or demand that holdings be subdivided into equal parts among the heirs which when the tradition continues among the subsequent generations, the same piece of land size of individuals decreases. The trend will ensure that as the population increases, not only does the size of holdings fall, but they are increasingly fragmented into small plots, scattered over a wide area (Bizimana, Nieuwoudt, \& Ferrer, 2004). This will ultimately result into smaller unsustainable and economically non-viable land holding units. Coupled with this is the increasing population pressure and uncontrolled land tilling leading to the growth of land markets.

The existence of fragmented land holdings is regarded as an important feature of less developed agricultural systems (Van Hung, MacAulay, Marsh, 2007; Hristov, 2009). This can be a constraint to agricultural development because it hinders agricultural modernization and efficient crop production, as well as involving large costs to alleviate its effects (Najeli, 2003; Thomas, 2006; Thapa, 2007; Tan, Heerink, Kruseman, \& Qu, 2008). Scholars for this view have put up with consolidated land could reduce travel times, boundary waste, feasibility of large scale productive investment, and ease supervision of labour among other benefits (Monehuk, Deininge, Bank, and Anand, 2010). On the other hand, those in favour of land fragmentation including Blarel et al, (1992), argued that land fragmentation is beneficial to farmers in managing risk, overcoming seasonal labour bottlenecks, and in matching soil types with necessary food crops. Policy makers took extreme view in favour of land consolidation considering various preventive legislations to reverse the land fragmentation trend, while economists adopt a balanced view arguing that land fragmentation can be adapted under certain circumstances but may become nonadaptive with changes in technology and factor costs. This view implies that the issue of land fragmentation takes a spatial-temporal dimension requiring a context specific evaluation while considering existing local socioeconomic and environmental conditions before any policy decision is made.

In the wake of dwindling land holdings and intensification, especially in developing countries there is a renewed interest in attempt to understand and resolve controversy surrounding the impact of land fragmentation on food production (Demetriou et al, 2013; Wan and Cheng, 2010; Saver et al, 2012). The major concern in Africa today is the declining mean farm size and fallow period over time within densely populated small holder farming areas where more than half rural farm households control one hectare of farm land (Jayne, Chambelin, and Muyanga, 2012). The disparity of land holding cast doubt to the sustainability of food production sufficient for household subsistence and market surplus.

In view of these considerations, numerous land consolidation and land reform policies have been implemented in European and African countries like Netherlands, France, Kenya, Tanzania, Rwanda and Nigeria 
(Sabates-Wheeler,2002; Sundqvist and Andersson, 2006). In Nigeria, the intervention into the land problem involves the promulgation of the 1978 Land Use Act.

This law has yielded not enough outcomes in the agricultural sector in Nigeria in general and Benue state in particular. Hence, Gwer-West Local Government Area where the research was conducted still faces problems of land fragmentation. In Benue State also, the demand for land became high due to the rapid growth of human population with the growing mouth to feed, the natural (sustainable or viable) agricultural practices are abandoned, pressures are mounted on the pieces of land available, the fallow periods have been reduced from 5-7 years to less than 2 years or non-existence in most places (Nyagba, 1995). This study is hoped to create awareness, encourage the masses, enlighten and mobilise the masses as well as policy makers (government) about the empirical negative impact of land fragmentation on crop production leading to the sustainable development of the entire Gwer West Local Government Area in particular and Benue State in general.

One of the common features of agriculture in the contemporary developing states of the world is the conspicuousness of agricultural land fragmentation (Niroula and Thapa, 2007). This phenomenon has opposing influences on agricultural crop production as while some scholars see it as being beneficial to farmers, others see it as an inimical or detrimental phenomenon to a viable agricultural crop production (Laure and Laurent, 2013).

Fragmentation exhibited in spatial extent (size) and the dispersion of plots both have impact on crop production because when the plots are scattered, it becomes very difficult to grow certain crops and this prevents farmers from changing to high profit crops like fruit crops which require larger plot areas and so, if the farmers only possess small and fragmented plots they may be compelled to grow only less profitable crops (The World Bank, 2005). Even though scattered plots may in another way benefit farmers to overcome perils like flood, fire and diseases, ownership of small fragmented plots when not deliberate is often related to low fertility and high cost which seriously affect output and its profitability as a result of low fallow durations.

In areas of high population density such as the Kano close-settled zone, land may be owned by individuals and passed on from father to his son(s). When a man dies in such areas, his land is split among his sons thus, unless the heirs have been able to add to the original total holding through purchase for example, the successive fragmentation of land will mean that the amount of land available to average person in the family continues to decrease. The problems of family ownership and communal ownership of land were some of the reasons why government enacted the Land Use Act of 1978 with the main objective of making land for development readily available to individuals, groups, institutions and government, unfortunately the land use act has yielded not enough outcome because in its presence;

i. $\quad$ ordinary Nigerians are experiencing immense difficulty in securing land under the act while conversely.

ii. influential Nigerians find it easy to acquire vast areas of land originally belonging to poor and illiterate rural dwellers, leading to serious land problems today.

Land fragmentation is more often believed to be one major problem existing in rural land management, because it has been viewed as an obstacle to agricultural productivity and modernization. It used to be closely associated with Europe, but it has been documented in other parts of the world like in Taiwan, Malaysia, Japan, the United States, and especially in developing countries like Kenya, Uganda, Nigeria, Peru, Rwanda, Ghana and Ethiopia (Rusu, 2002). The absence of real standard objective measure of land fragmentation makes comparisons between countries difficult and makes it hard to decide when a farm is too fragmented (Sundqvist and Anderson, 2006).

\section{MATERIALS AND METHODS \\ Study Area}

This study was conducted in Gwer West and Gwer East LGAs of Benue State. Gwer West LGA is located between latitudes 9 and $12^{\circ} \mathrm{N}$ and longitudes 6 and $9^{\circ} \mathrm{E}$. It is bounded by Makurdi and Guma LGAs to the north, Gwer East LGA to east, Otukpo LGA to the South and Apa and Agatu LGAs to the West. The headquarters of the LGA is Naka which is strategically located at killometre 40 along the Makurdi - Ankpa interstate road (see figure 1 and 2). 


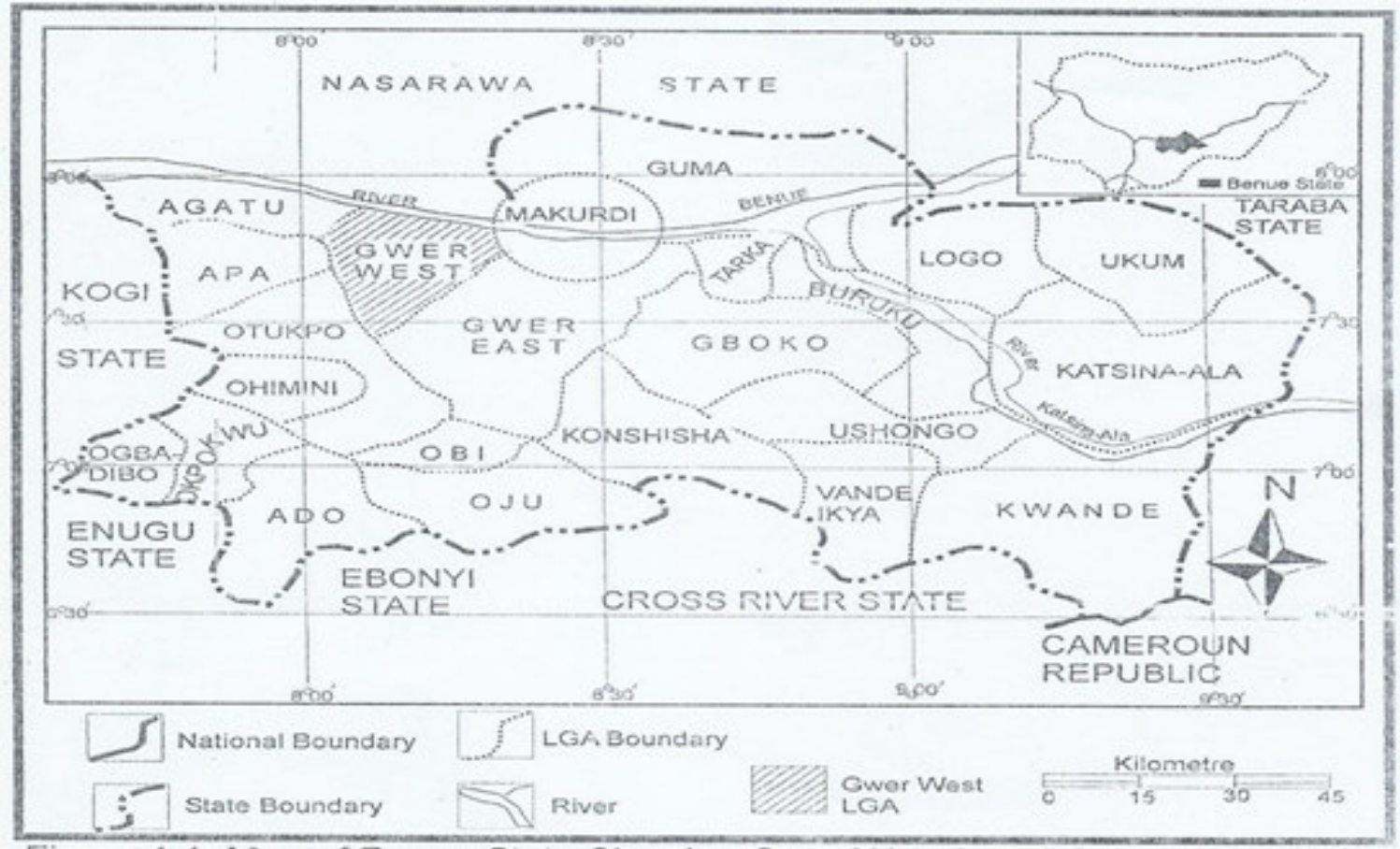

Figure 1: Benue state showing the study area

Source: Ministry Lands, Makurdi



Figure 1: Benue state showing the study area

Source: Ministry Lands, Makurdi

Gwer West was created out of the former Gwer local government in 1991with Naka as its administrative headquarters during the regime of military president Ibrahim Badamosi Babangida. It covers a landmass of about $1,094 \mathrm{~km}^{2}$. Presently, the Makurdi -Naka-Adoka -Ankpa and the Taraku- Aondona Naka-Agagbe roads almost 
divide Gwer west along the former road strategically at $40 \mathrm{~km}$ (in Naka) into four nearly equal parts on any updated political map of the study area.

The local government is traversed and drained by many rivers including Gwer, Cheku, Akpaku, Nagi, Chu, Ana, Michi, Kpeele, Kpukulu, Acha. Most of these rivers are ephemeral or seasonal in nature with a few being perennial but however reducing water volume in the dry season. These rivers take their sources mostly from the southern, western or eastern parts or neighbourhood of the local government. Meanwhile, discharge is indirectly or directly into River Benue, northward of the study area. This is due to the generally gentle but undulating slope in the area slightly getting lower towards River Benue.

The local government has four area development (units) offices of Udam, Achamegh/Ayemegh, Mbakyoondu, and Sengev/Gaambe. It also has fifteen council wards of Mbachohon, Mbapa, Mbabuande, Mbapupuu/Tswarev, Sengev, Gbange/Tongov, Tyoughategher/Injaha, Saghev/Ukusu, Ikyaghev, Tsambe/Mbesev, Sengev/Yengev, Tijime, Avihijime, Merkyen, and Nyamshi.

Settlement pattern here is nucleated villages in the countryside as well as towns like Naka, Atukpu, Agagbe, Nagi, Aondona, and to some extent, a gradually emerging Goh. This pattern is assumed in towns because of survey plans while in the rural areas as a result of traditional belief/family ties and system of agriculture which demands vast expanse of land. There are also some elements of linear pattern along the roads.

The population of Gwer-west Local Government area according to the national population census (2006) was 123,313. Majority of the indigenous population is Tiv (Tyoshin people) with Injaha people of Idoma constituting another set of indigenous population but in few numbers. They are settled on the banks of River Benue in Tyoughatgher/Injaha council ward, north of the local government. Other ethnic nationalities found here include but not limited to Hausa, Yoruba, Igala, Igede, Ijaw, Urhobo, Etulo, Edo.

Most of the people are soil dependents i.e they earn their living directly through peasant farming as a primary and in most cases principal pre-occupation. A few of the population comprise of lumbermen, fishermen, hunters, traders, transport workers (service activities), the clergy and civil/public servants. Crops of diverse species are cultivated here which include Yam, Maize, Cassava, Rice, Sorghum, Soya beans, Sesame, Beans as well as spice and horticultural species. Generally, there is low exploration and exploitation of mineral resources.

The study area also has some important settlements some of which are urban, peri-urban while others are highly influenced by urban conditions and are almost all equally having periodic market centres serving as media for the exchange of goods, services and information. These include Naka, Agagbe, Aondona, Nagi, Atukpu, Kyande, Namikpe, Bunaka, Goh (Afogba), Koti-Akpoughul, Anguhar and Tse-Achagh. Some of these markets attract patronage from far away areas even beyond Benue state.

\section{Methods}

In this particular work, the survey research technique is employed due to non-availability of stored data by relevant authorities concerning the problem in the study area. The researcher will therefore, obtain data directly from the farmers through oral interviews/focus group discussions and questionnaire administration which will be supplemented by data obtained through observation and physical measurement of some attributes. Data on farm sizes in the study area include information on sizes of farm plots/parcels, their contiguity or proximity to one another. Data is also needed on the factors of land fragmentation which may include population, competition on arable land by other human needs like urbanisation/habitation. There is data requirement on the impact of land fragmentation in terms of; the type of crops permissible for gainful cultivation, amount of crop yield in quantity per unit of land, amount of agricultural input or cost that gives an output per unit of farm land.

The population of interest here is strictly the adult people who engage or had involved themselves in the activities of agricultural production in Gwer West LGA for a period of not less than twenty years. Study area of the research is divided into two major clusters; Raav and Mbakpa with four area development offices of Udam, Achamegh/Ayemegh, Mbakyoondu and Gaambe/Sengev and fifteen council wards,each having five kindreds. A sample size of fifteen farms was selected for critical inquiry. A sample size of 398 respondents was distributed equally among five council wards: Tijime, Mbachohon,Tsambe/Mbesev, Mbabuande, Gbaange/Tongov in Gwer West Local Government Area, Benue State (see Figure 3) 


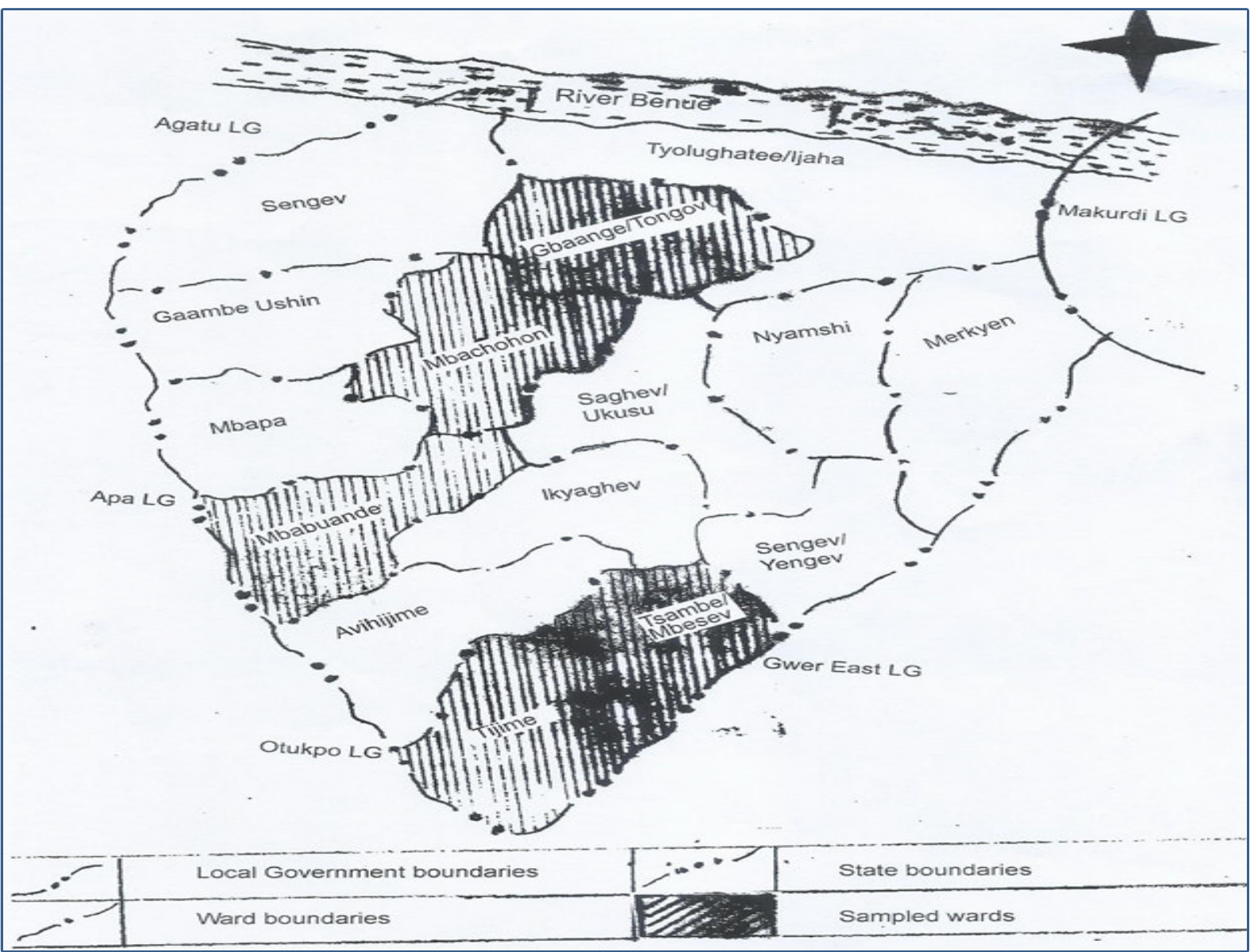

Figure 3 Gwer West showing the sample wards in the study area

Source: Ministry of lands and Survey, Makurdi (2019)

Various sampling techniques were employed to arrive at choice of samples. Here, the selection of sampling techniques to make for the representation of population include: multi-stage random sampling, simple random sampling and systematic random sampling techniques. The multi-stage random sampling technique was first employed to select the sample areas starting from the two major divisions of Gwer West to the four area development offices. One ward was selected from each area development office with the fifth ward added from Gaambe/Sengev area development office due to the fact that it has the highest number of council wards (five) and it is also believed to be having the highest population among the other area development offices of Udam, Achamegh/Ayemegh and Mbakyoondu.

The five council wards selected were based on their rural nature and geographical location away from the main urban centre (Naka) in the study area. This was done so in order to evade the influence of urban population on land through its unnecessary pressure. There was no discrimination on the uniform five kindreds from each of the five council wards selected. The simple random sampling technique was used in making the choice of specific farms selected for close observation or critical inquiry. Here, the researcher made use of table of random numbers, that is, list of farms at the selected wards to make up the sample of farm population in this regard. Similarly, a sample of respondents to questionnaires was arrived at through the adoption of systematic random sampling technique. A list of potential/anticipated respondents was designed for the wards and then, a selection of ten compounds made where questionnaires were administered, an activity which was repeated at regular interval after ten compounds until questionnaires for each ward were exhausted.

Data for the research will be collected through field work using questionnaires/focus group discussions so that information can be obtained from the farmers directly, and observation of features. For ease of understanding, the researcher has decided to present the result from data analysis in simple tables to be converted to percentages so that comparison can be made possible between one variable and the other.

\section{RESULTS AND DISCUSSION}

\section{Socio-Demographic Characteristics}

The study assessed the socio-demographic characteristics of farmers in the area considering specific variables such as age, marital status, educational attainment and household size. Information on the socio-demographic 
characteristics is presented on table 1 .

Table 1: Socio-demographic characteristics of respondents

\begin{tabular}{|c|c|c|c|}
\hline $\mathbf{S} / \mathbf{N}$ & Research Item & Frequency & Percentage (\%) \\
\hline & Age of Respondents & & \\
\hline 1 & $31-40$ years & 123 & 31 \\
\hline 2 & $41-50$ years & 115 & 29 \\
\hline 3 & $51-60$ years & 68 & 17 \\
\hline 4 & $61-70$ years & 56 & 14 \\
\hline \multirow[t]{2}{*}{5} & 71years and above & 36 & 9 \\
\hline & Marital Status of Respondents & & \\
\hline 1 & Single & 35 & 9 \\
\hline 2 & Married & 295 & 74 \\
\hline 3 & Separated/Divorced & 24 & 6 \\
\hline \multirow[t]{2}{*}{4} & Widowed & 44 & 11 \\
\hline & Educational Attainment & & \\
\hline 1 & Non-formal & 147 & 37 \\
\hline 2 & Primary & 107 & 27 \\
\hline 3 & Secondary & 84 & 21 \\
\hline \multirow[t]{2}{*}{4} & Tertiary & 60 & 15 \\
\hline & Household size & & \\
\hline 1 & $1-3$ & 76 & 19 \\
\hline 2 & $4-6$ & 139 & 35 \\
\hline 3 & $7-9$ & 115 & 29 \\
\hline \multirow[t]{2}{*}{4} & 10 and above & 68 & 17 \\
\hline & Total & 398 & $100 \%$ \\
\hline
\end{tabular}

Source: Fieldwork, 2019

Table 1 show that $31.0 \%$ of the respondents are within the age group of $31-40$ years, $29.0 \%$ within the age group of $41-50$ years, $17.0 \%$ are within the age group of 51-60 years, $14.0 \%$ are within the age group of $61-70 y e a r s$ while, $9.0 \%$ are within the age group of 71 years and above. The respondents' mean age of 50years which means that the most of the participants were participating actively in farming activities for more than 20years ago and could give information on farming activities for the past 20 years and also the present situation in 2019. Marriage status shows that 295 of the farmers are married with average household size of 7-9 persons represented by $70 \%$ of the respondents. The level of education of farmers indicated that majority of the farmers represented by $37 \%$ have no formal education, $27 \%$ have primary education, while $21 \%$ have secondary education.

\section{Past and Present Farm Land attributes}

Information obtained indicates that there high total stock ownership of land in the past 20 years. This was however prior to wide adoption and massive use of modern agro-chemicals especially herbicides, tree killers and some other agro-based biocides as well as widespread use of modern genetically improved or modified species/varieties of crops which made crop production relatively less attractive then. Even with such level of stock ownership, the farmers reported that fields under fallow were almost always equivalent to those under cultivation with factors ranging from the population size at that time, the views of many people then that agriculture was a venture of the uneducated, the economic policies which favoured importation against export of local crop produce, absence of effective loan schemes and the near absence of processing industries that could stimulate robust cultivation.

However, there has been a notable change in total land stock ownership accompanied by changes in the nature of these factors that had earlier impeded massive crop production leading to more land being put under crop production today, the result of which is a rising fragmentation of more land, details is presented on Table 2 below; Table 2: Past and Present Stock of Land Ownership

\begin{tabular}{lcccc}
\hline & \multicolumn{2}{c}{ Past (last 20 years) } & \multicolumn{2}{c}{ Present (2019) } \\
\cline { 2 - 5 } Stock Size(Ha) & Respondents & Percentage (\%) & Respondents & Percentage (\%) \\
\hline$<$ hha & 28 & 7 & 36 & 9 \\
1-3ha & 24 & 6 & 48 & 12 \\
4-6ha & 36 & 9 & 68 & 17 \\
7-9ha & 75 & 19 & 115 & 29 \\
10ha + & 235 & 59 & 131 & 33 \\
Total & $\mathbf{3 9 8}$ & $\mathbf{1 0 0}$ & $\mathbf{3 9 8}$ & $\mathbf{1 0 0}$ \\
\hline
\end{tabular}

Source: Researcher's Fieldwork, 2019 


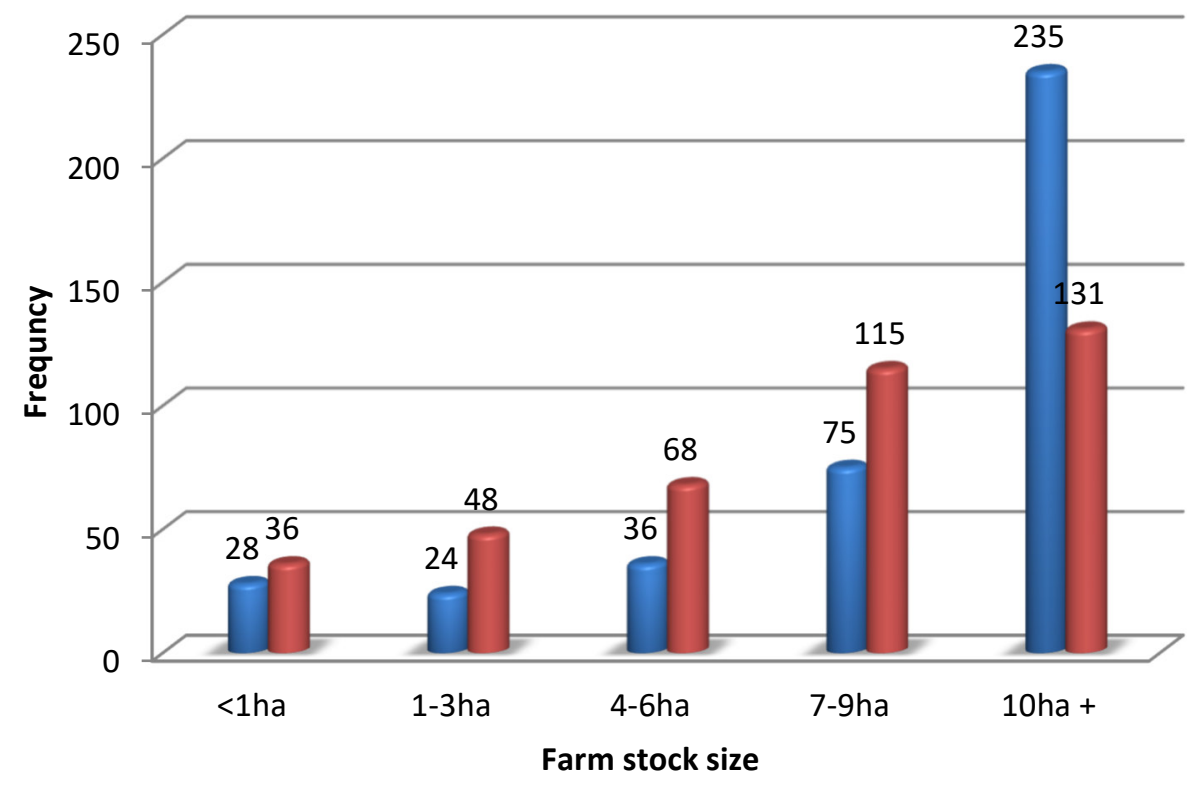

20years ago

Present_2019

Figure 3: Total Land Stock ownership 20years ago and 2019

Information on Table 2 and Figure 3 shows that total land stock ownership decline over the past 20years. The Table shows that 20 years ago, 235 respondents represented by $59 \%$ of the respondents owned land stock of more 10 hectares, 75 respondents representing $19 \%$ of the respondents owned land stock of 7-9 hectares, 36 representing 9\% had 4-6 hectares, 24 respondents (6\%) owned 1-3 hectares and only 28 respondents owned stock of land that were less than a hectare representing $7 \%$ of the respondents. However, due to some dynamic factors earlier mentioned only 131 respondents were having land stock of 10 hectares and above representing $33 \%$ of the respondents, 115 of the respondents representing 29\% were having between 7-9 hectares total land stock, 68 respondents representing $17 \%$ have $4-6$ hectares while only 48 respondents have $1-3$ hectares making up $12 \%$ as 36 respondents representing $9 \%$ own less than a hectare today. Total land stock ownership declined significantly which leads to decreased farm sizes. The information on decreased farm sizes in presented on Table 3.

Table 3: Past and Present Farm Size

\begin{tabular}{lcccc}
\hline & \multicolumn{2}{c}{ Past (last 20 years) } & \multicolumn{2}{c}{ Present (2019) } \\
\cline { 2 - 5 } Farm Size(Ha) & Respondents & Percentage (\%) & Respondents & Percentage (\%) \\
\hline$<1$ ha & 127 & 32 & 175 & 44 \\
$1-2$ ha & 103 & 26 & 111 & 28 \\
$3-4$ ha & 96 & 24 & 60 & 15 \\
5ha + & 72 & 18 & 52 & 13 \\
Total & $\mathbf{3 9 8}$ & $\mathbf{1 0 0}$ & $\mathbf{3 9 8}$ & $\mathbf{1 0 0}$ \\
\hline
\end{tabular}

Source: Researcher's Fieldwork, 2019 


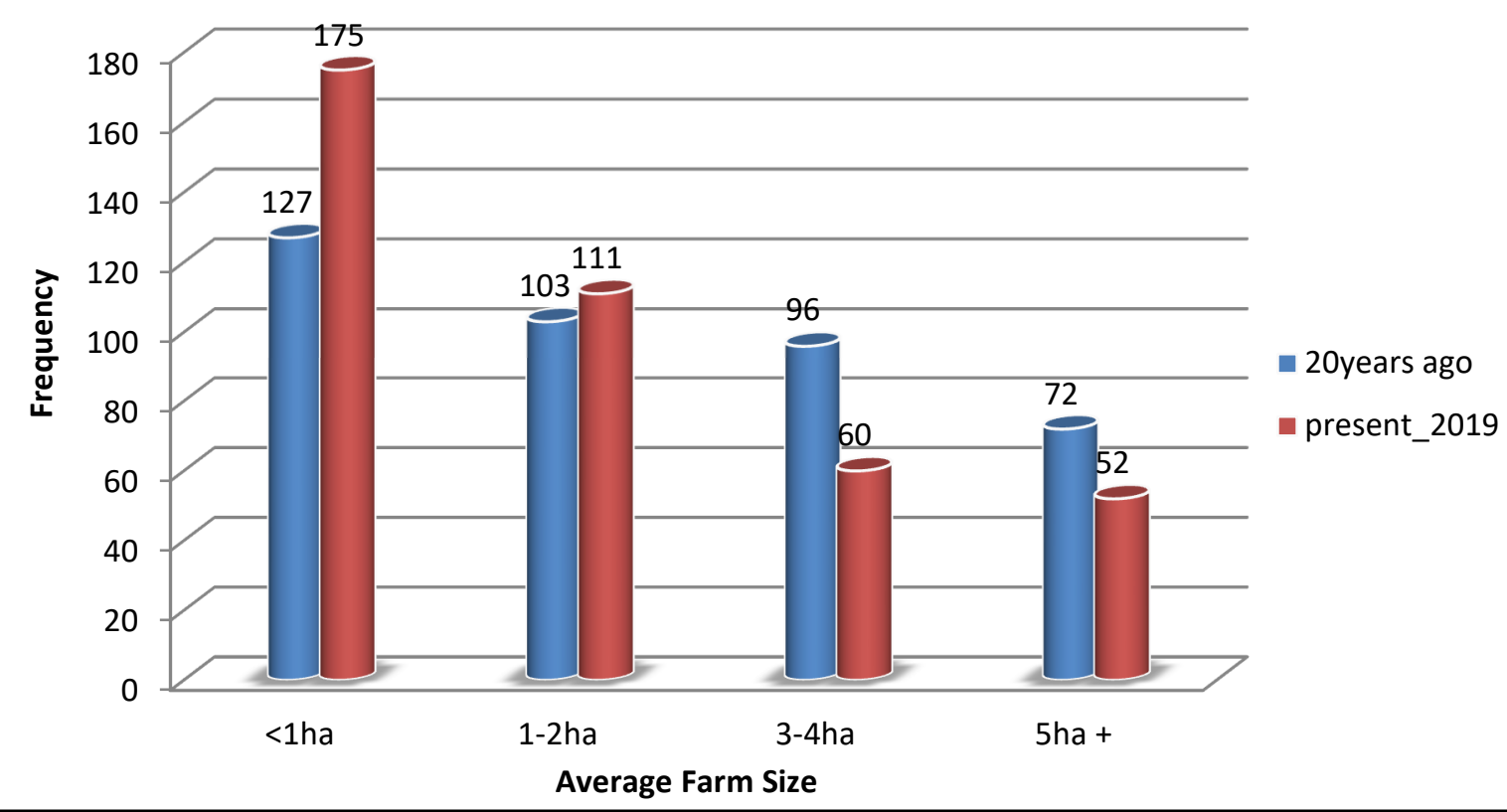

Figure 4: past (20years ago) and present (2019) farm size

Table 3 shows that reduction in land stock ownership has a relationship with changing plot size as land has to be given to new crop production. The Table shows changing plot sizes in the study area from the past 20 years to the present time. In the past 20 years, only 127 respondents representing 32\% reported that their plots used to be less than a hectare, 103 respondents representing 26\% said their plot size was between 1-2 hectares, 96 respondents representing $24 \%$ had plot size of between 3-4 hectares while 72 representing $18 \%$ owned plots size of 5 hectares and above. Presently, 175 respondents representing 44\% have plot size less than a hectare, 111 farmers have plot sizes of between 1-2 hectare representing $28 \%, 15 \%$ of the farmers have plot size of $4-6$ hectares and just $13 \%$ of the farmers have plot sizes of 5 hectares and above, an indication of how fast fragmentation in size is going on in the study area.

Number of farm plots ownership increased over the time period as result of land fragmentation. Field data revealed that as plot sizes were relatively large, ownership of same in numerical quantity per farmer was rather less due to the large sizes of parcels. This has changed today as the respondents reported increase in ownership of small plot sizes due to the overwhelming pressure mounted on land by an over-growing population through high birthrates, return or in-migration emanating from security uncertainties in the country. Information on changing number of farm plots ownership over the period of time is presented on Figure $\mathrm{X}$ 


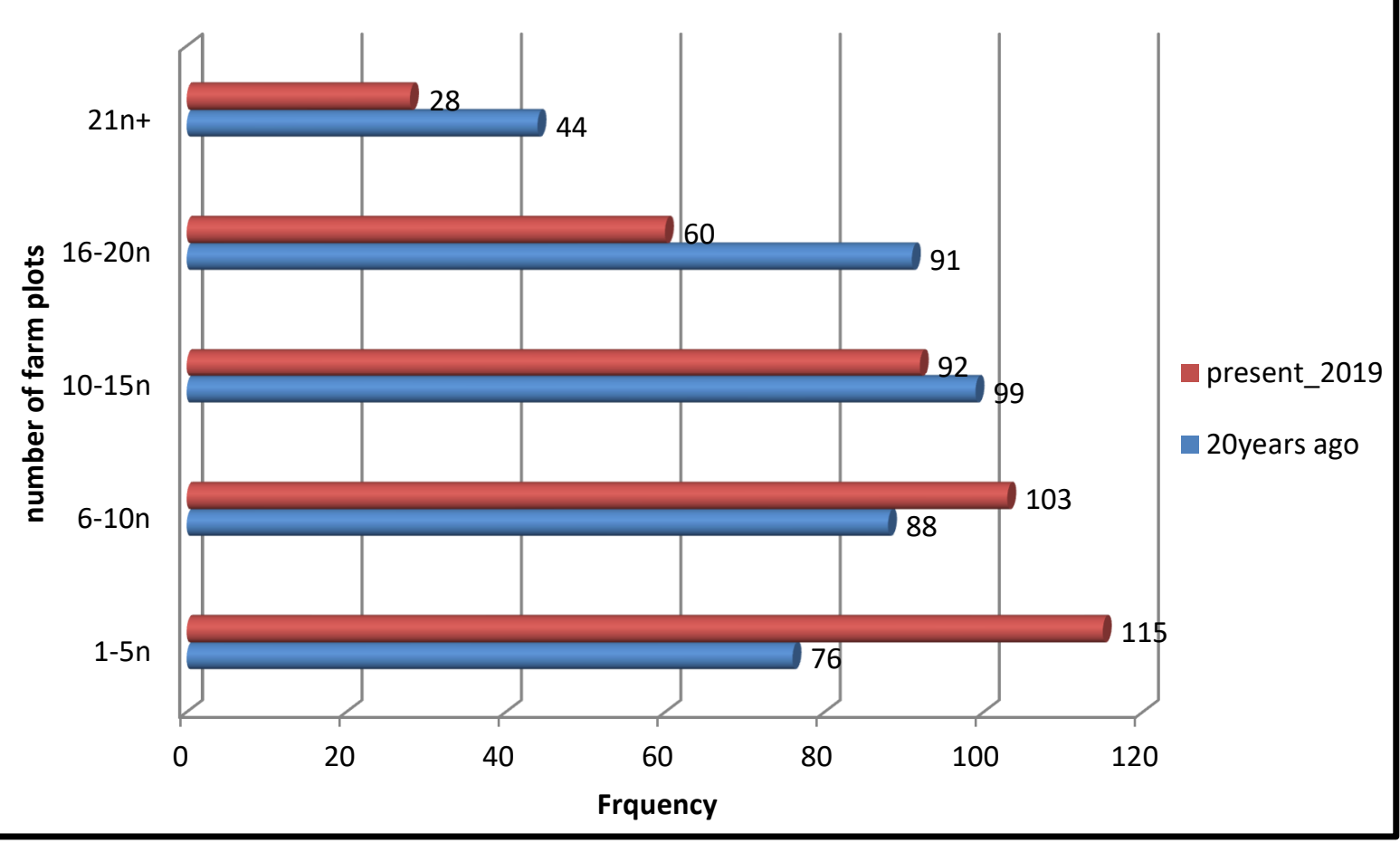

Figure 4: Changing number of farm plots ownership

The farm plots ownership has increased but size decreased. In the past 20 years, $19 \%$ of the farmers had $1-5$ number of farm plots as against $29 \%$ of the farmers presently having today. Also, $22 \%$ of the farmers owned $6-10$ parcels of farm land while presently $26 \%$ of the farmers have 6-10 farm plots, $25 \%$ of the farmers were having 11 15 parcels but today, it is $23 \%$ are having same number. In addition, $23 \%$ farmers had between $16-20$ parcels of farm land while $15 \%$ of the farmers have 16-20 parcels of land. Lastly, it is also very clear that those having from 21 parcels and above were $11 \%$ while $7 \%$ of the farmers presently have 21 parcels of land today.

\section{Impact of Land Fragmentation on Crop Production}

Changing farm size has affected crop production in terms of type of crops produced, land use pattern, crop yield and the fertility of the soil. Information on crops produced in the area 20 years ago and what is produced presently.

Table 4: Major Crops Produced in the Study Area

\begin{tabular}{lcccc}
\hline \multirow{2}{*}{ Crop } & \multicolumn{2}{c}{ Past (last 20 years) } & \multicolumn{2}{c}{ Present (2019) } \\
\cline { 2 - 5 } & Respondents & Rank & Respondents & Rank \\
\hline Maize & 139 & 1 & 52 & 3 \\
Cassava & 115 & 2 & 103 & 1 \\
Yam & 56 & 3 & 28 & 6 \\
Guinea corn & 40 & 4 & 99 & 2 \\
Soya beans & 16 & 6 & 16 & 7 \\
Rice & 24 & 5 & 64 & 3 \\
Beni seed & 8 & 7 & 36 & $\mathbf{1 0 0}$ \\
Total & $\mathbf{3 9 8}$ & $\mathbf{1 0 0}$ & $\mathbf{3 9 8}$ & \\
\hline
\end{tabular}

Source: Researcher's Field Work (2019)

The major crops produced 20 years ago include the following: maize, cassava, yam, guinea corn, rice and soya beans ranked from the most important to the least important crop produced. This is an indication that most of the crops produced 20 years ago were more of food crops for household consumption. Presently, the crops produce in their order of importance include the following: cassava, guinea corn, rice, maize, beni seed, and yam. There is a gradual shift from the production of food crops to cash crops and commercialized food crops such as cassava, rice, beni seed (See Figure 4). 


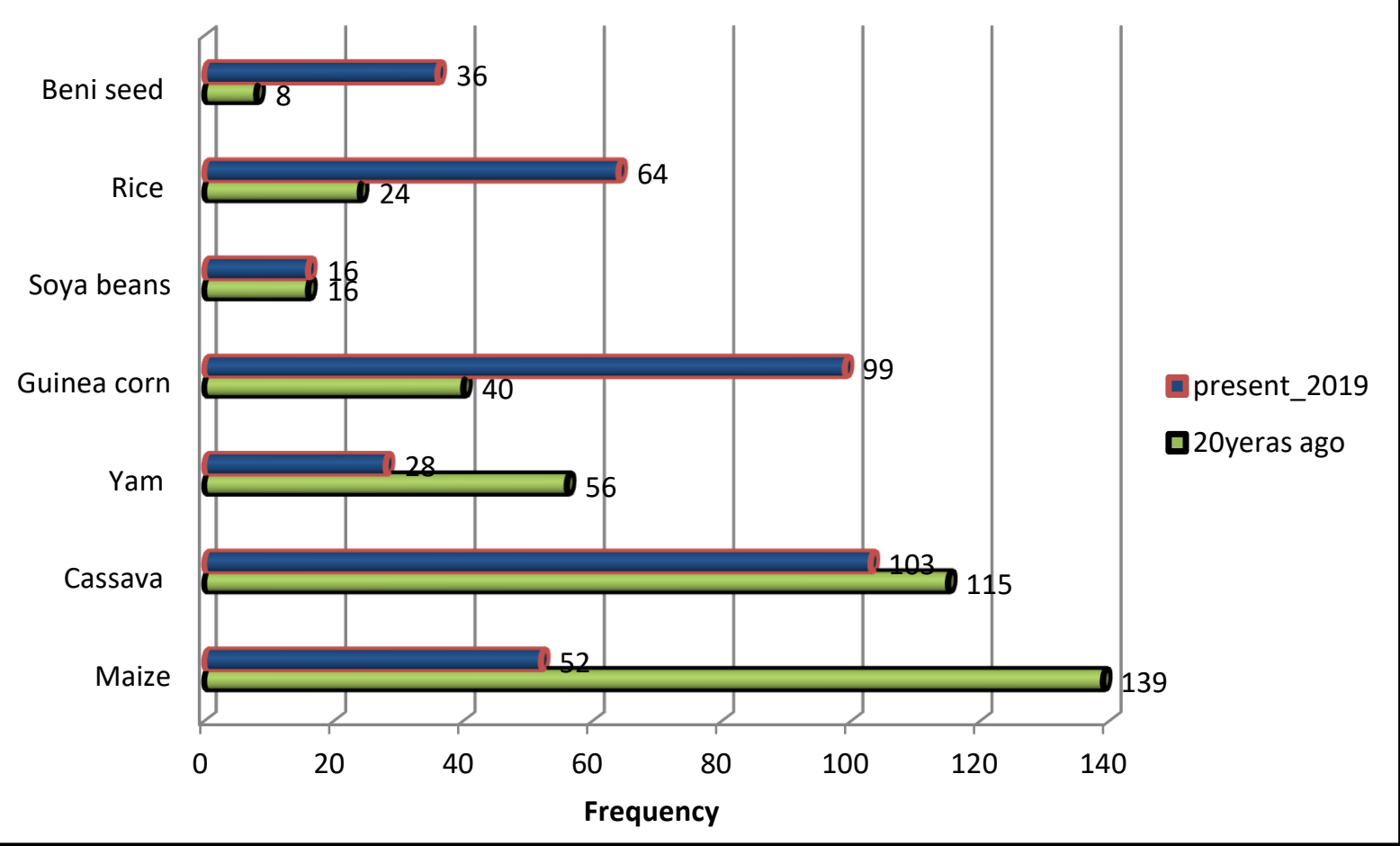

Figure 4: Crops produced 20 years ago and current types of crops produced in the area.

Crop yield per farmer has declined over time due to declining farm size and soil fertility within the area. Information on crop yield 20 years ago and the current crop yield is presented on Table 5 .

Table 5: Annual Yield in Bags

\begin{tabular}{lcccc}
\hline \multicolumn{1}{c}{ Yield in } & \multicolumn{2}{c}{ Past (last 20 years) } & \multicolumn{2}{c}{ Present (2019) } \\
\cline { 2 - 5 } Bags(100kg) & Respondents & Percentage (\%) & Respondents & Percentage (\%) \\
\hline $1-5$ & 44 & 11 & 84 & 21 \\
$6-10$ & 75 & 19 & 123 & 31 \\
$11-15$ & 183 & 46 & 107 & 27 \\
$16-20$ & 68 & 17 & 60 & 15 \\
$21+$ & 28 & 7 & 24 & 6 \\
Total & $\mathbf{3 9 8}$ & $\mathbf{1 0 0}$ & $\mathbf{3 9 8}$ & $\mathbf{1 0 0}$ \\
\hline
\end{tabular}

Source: Researcher's Field Work (2019)

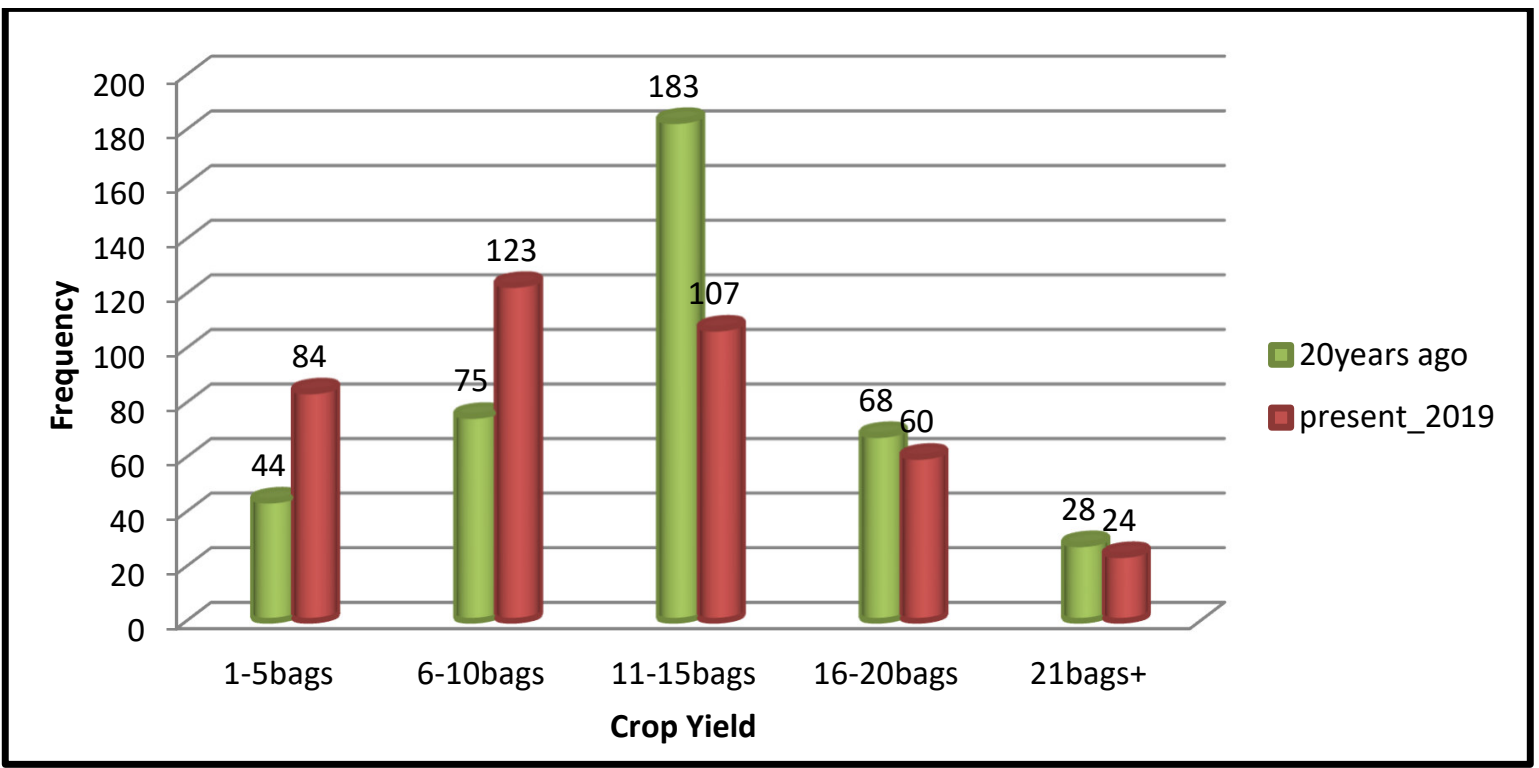

Figure: Past and present Crop yield in the Area

Table shows that we can 20 years ago, 44 farmers representing $11 \%$ of the respondents produce $1-5$ 
bags $(100 \mathrm{~kg}), 75$ representing $19 \%$ of the farmers produced $6-10$ bags, 183 farmers representing $46 \%$ of the respondents produced 11-15bags, 68 of the selected farmers representing 17\% of the respondents produced 16-20 bags while 28 respondents representing $7 \%$ of the farmers produce 21 bags and above. However, there serious decline in the quantity of crop produced. Current crop yield shows that 84 farmers representing $21 \%$ of the farmers produce between $1-5$ bags, 123 of the respondents represented by $31 \%$ produce $6-10$ bags, 107 of the respondents representing $27 \%$ of the farmers produce $11-15$ bags, 60 of the respondents representing $15 \%$ of the farmers produce 16-20 bags while only 24 respondents representing $6 \%$ of the respondents are produce 21 bags and above.

In order to improve agricultural productivity in the area, Farmers are gradually shifting from extensive agricultural land use to intensive agricultural land use. Information on change in agricultural land use is presented on Table 6.

Table 6: Changes in Popular Land Use

\begin{tabular}{lcccc}
\hline & \multicolumn{2}{c}{ Past (last 20 years) } & \multicolumn{2}{c}{ Present (2019) } \\
\cline { 2 - 5 } Land Use & Respondents & Percentage (\%) & Respondents & Percentage (\%) \\
\hline Mixed Farming & 56 & 14 & 60 & 17 \\
Shifting Cultivation & 4 & 1 & 0 & 0 \\
Rotational Bush Fallowing & 219 & 55 & 75 & 19 \\
Intensive Farming & 24 & 6 & 295 & 49 \\
Permanent Cultivation & 8 & 2 & 44 & 11 \\
Extensive Farming & 87 & 22 & 16 & 4 \\
Total & $\mathbf{3 9 8}$ & $\mathbf{1 0 0}$ & $\mathbf{3 9 8}$ & $\mathbf{1 0 0}$ \\
\hline
\end{tabular}

Source: Fieldwork, 2019

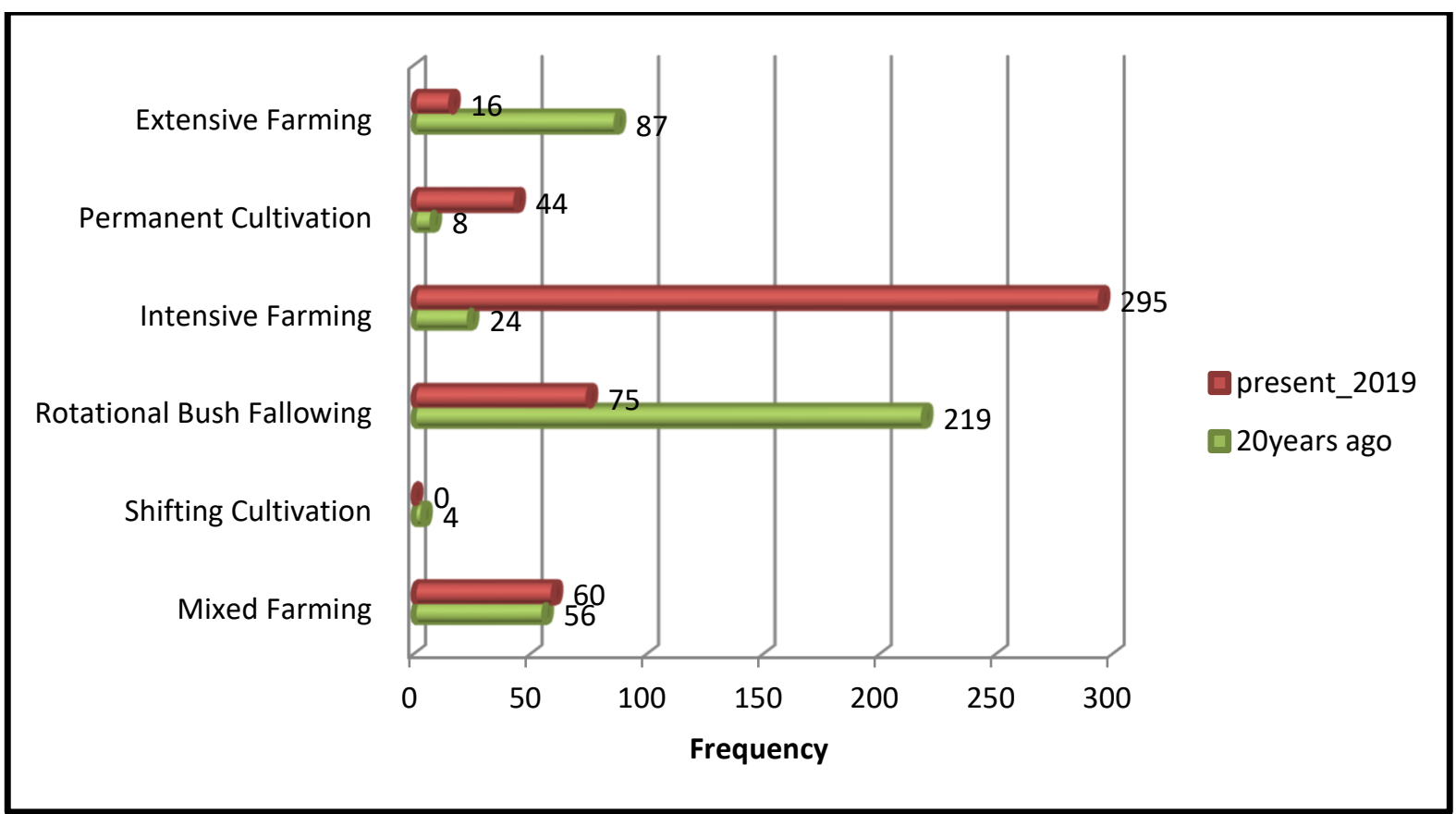

Figure: Change in agricultural land use due to land fragmentation

Table 6 shows that, $55 \%$ of the farmers 20 years ago were practicing rotational bush fallowing, followed by $22 \%$ of the farmers practicing extensive farming while $14 \%$ of the farmers practicing mixed farming. Whereas, land fragmentation and other factors creating pressure on land demand, $49 \%$ of the farmers adopted intensive farming, $19 \%$ of the farmers are still practicing rotational bush fallowing, and $17 \%$ of the farmers have adopted mixed farming while shifting cultivation is no longer in practice.

\section{Causes of Changing Farm Sizes in the Study Area}

Access to land is very essential in crop production because the mode through which access to land is realized determines to some extent, the level of land maintenance that is given to the land for efficient agricultural activities. For instance, access through inheritance almost always transcends to ownership of such a piece of land without any financial expenditure by the new owner. In a similar way, access through gift especially where it is not temporary, entails no capital cost on the new owner and all these may motivate farmers to give such lands the best attention it deserves and also plan their activities more appropriately. On the contrary, access through purchase and pledge always involve economic transactions between two or more.Several factors have been revealed 
through investigation as causing land fragmentation in the study area ranging from the system of land ownership, choice making by farmers, rapid population growth, monetization, scope of the economy to several others like government interference and court verdicts. Information on causes of land fragmentation is presented on Table 7

\section{Table 7: Causes of land fragmentation}

\begin{tabular}{lcc}
\hline Factors & Respondents & Percentage (\%) \\
\hline Inheritance & 298 & 75 \\
Farmers' Choice & 12 & 3 \\
Population Growth & 48 & 12 \\
Monetization & 4 & 1 \\
Homogenous Economy & 20 & 5 \\
Government Interference & 8 & 2 \\
Court Verdict & 8 & 2 \\
Total & $\mathbf{3 9 8}$ & $\mathbf{1 0 0}$ \\
\hline
\end{tabular}

Source: Researcher's Field Work(2019).

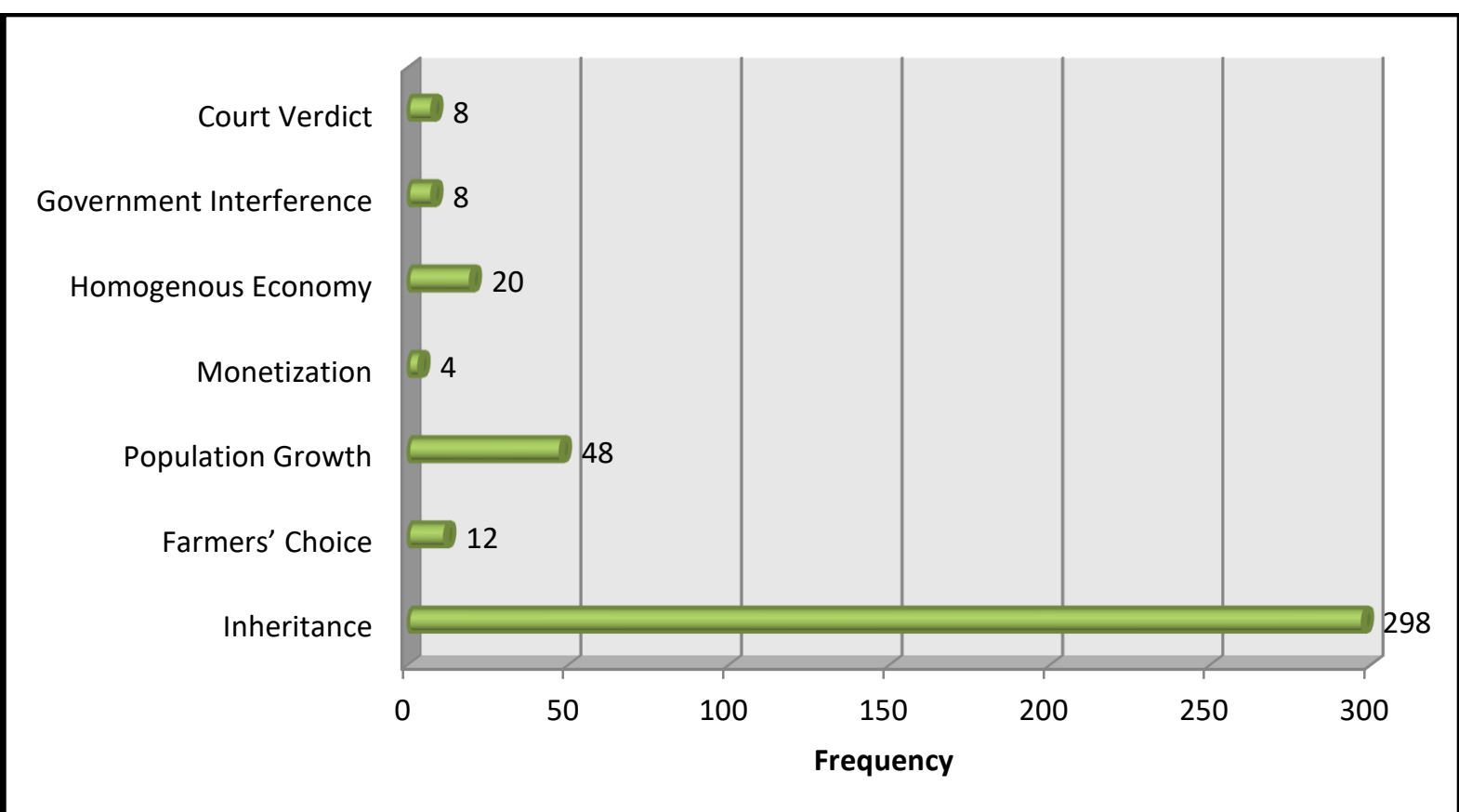

Figure: Causes of land fragmentation

Information on Table 5 shows that, $75 \%$ of the farmers affirmed that inheritance is the main cause of land fragmentation in the area. Inherited land is shared among the offspring which result to decreased sizes of farm plots. Population growth is another factor causing land fragmentation in the area. This evident as $12 \%$ of farmers indicated population increase as one of the drivers of land fragmentation in the area. Other factors include: homogenous economy (5\%), farmers' choice (3\%) and government interference and court verdict $(2 \%)$.

\section{Mechanisms to Handle Fragmentation}

Different suggestions have arose concerning preferred frameworks or mechanisms that can best be used in handling the problem of land fragmentations starting from land consolidation, economic diversification, education/extension services to population control, agricultural reforms and several others. Information on ways of handling land fragmentation in the area is presented on Table 8.

Table 8: Mechanisms for Handling Land Fragmentation

\begin{tabular}{lcc}
\hline Mechanisms & Respondents & Percentage (\%) \\
\hline Land consolidation & 59 & 21 \\
Economic diversification & 85 & 30 \\
Population control & 47 & 16 \\
Agricultural Reform & 39 & 14 \\
Education/Extension Services & 36 & 12 \\
Others & 21 & 17 \\
Total & $\mathbf{3 9 8}$ & $\mathbf{1 0 0}$ \\
\hline
\end{tabular}

Source: Researcher's Field Work (2019) 


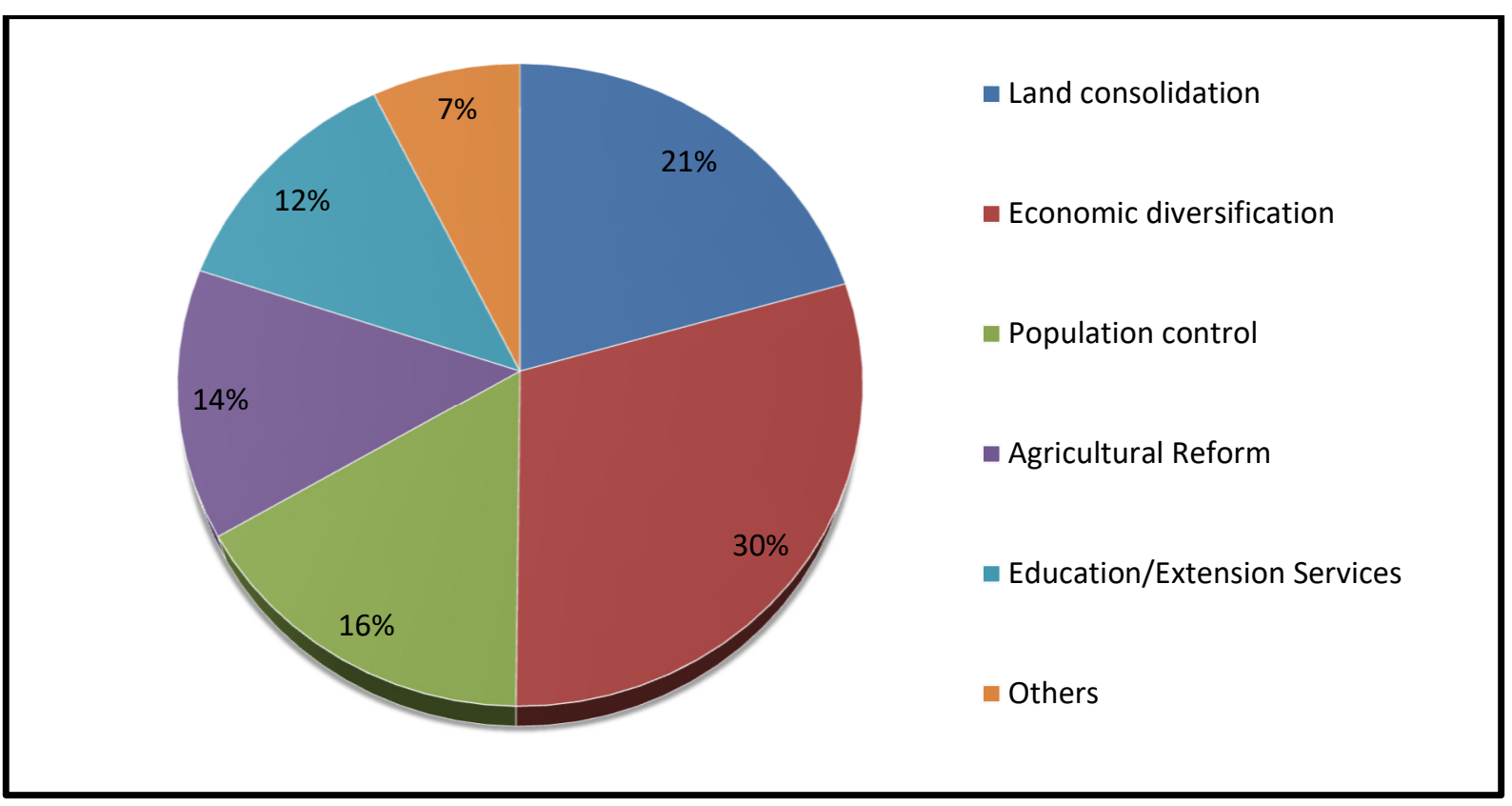

Figure: Suggested ways of handling land fragmentation

Table 8 shows that, $21 \%$ of the farmers affirmed that land consolidation can be used to reduce the impact of land fragmentation while $30 \%$ of the farmers agreed that economic diversification to other sectors than agriculture believing that if done, many farmers will swap from crop production therefore relieving pressure on land which will automatically lessen fragmentation. Cultural importance attached to number of children here is evident as only $16 \%$ of the farmers selected population control as measure for controlling pressure on land. The proponents of land fragmentation control are optimistic that if implemented, they will enjoy certain benefits which are presently difficult. Such advantages include easy access to loans, scale economies, more jobs, better care given to the land and a reduction in land being wasted in establishing boundaries and creating paths as well as reduction in frequent boundary disputes.

\section{CONCLUSION AND RECOMMENDATION}

It is very clear that land fragmentation negatively impacts crop production. A proper appreciation and understanding of the nature and impact of land fragmentation will stimulate an awareness of the need to put in place measures that will reduce the rate of land fragmentation and its impact on crop production the area. The recommendations made thereafter should strictly be abided so as to ensure better yield from this limited land because crop production is too essential to experience neglect. There should be a change in the way and manner in which land is owned through traditional inheritance system so that larger parcel sizes will be maintained with optimum global standards of contemporary crop production which will definitely lead to increased crop yield. Population growth should be controlled to conform with optimum arable land resources that can be available to individuals for gainful crop production. In so doing, the negative impact of land fragmentation can be minimised.

\section{REFERENCES}

Abawua, J.I. and Shabu, T. (2014). Concepts and Issues in Economic Geography. Makurdi. Climax Graphics and Publishers.

Bentley, W., (1987). Economic and ecological approaches to land fragmentation: In defence of a much-maligned phenomenon. Annual Review of Anthropology, 16, 31-67

Bizimana, C., Nieuwoudt, W., \& Ferrer, S. (2004). Farm size, land fragmentation and economic efficiency in Southern Rwanda. Agrekon, 43(2), 244-262. https://doi.org/10.1080/03031853.2004.9523648

Blarel, B., Hazell, P., Place, F., \& Quiggin, J. (1992). The economics of farm fragmentation: Evidence from Ghana and Rwanda. The World Bank Economic Review, 6, 233- 254. https://doi.org/10.1093/wber/6.2.233

Brabec, E., Smith, C., (2002). Agricultural land fragmentation: the spatial effects of three land protection strategies in the eastern United States. Landscape and Urban planning, 58 (2-4), 255-268.

Demetriou, D. (2013). Land Fragmentation (Chapter Two). In The Development of an Integrated Planning and Decision Support System (IPDSS) for Land Consolidation, pages 11-37.

Demetriou, D., Stillwell, J., and See, L. (2013). A new methodology for measuring land fragmentation. Computers, Environment and Urban Systems, 39:71-80.

Dovring F (1965). Land and labour in Europe in the twentieth century (3rd ed.). Hague: The Nijhoff. Edwards D 
(1961). An economic study of small farming in Jamaica. University College, West Indices.

Harris, John R. and Torado, Michael. P (1970) Migration, Unemployment and Development: A Two- Sector Analysis", American Economic Review, 60 (1): 126-142, JSTOR 1807860

Hristov, J (2009) "Assessment of the impact of high fragmented land upon the productivity and profitability of the farms -The case of the Macedonian vegetable growers". SLU, Department of Economics Thesis 561 Degree Thesis in Business Administration Uppsala.

Jayne,T.S,Chambelin,J.,andMuyanga,M.(2012).EmerginngLadIssuesinAfricanAgriculture: Implications for food security and poverty reduction strategies. In Stanford Symposium Series on Global Food Policy and Food Security in the 21 st Century, January, 12, pages 1-42.

Karangwa Mathias (2010) the of land fragmentation on the productivity and technical efficiency of smallholder maize farms in Southern Rwanda. Memoire Online. (ILEOJE, 2001)

Laure L. and Laurant P. (2013) Does land fragmentation affect farm performance? A case study from Brittany, France, Working Paper SMART - LERECO N¹3-04

McPherson, M.F. (19820. Land fragmentation: A selected literature review. Cambridge: Harvard University, Harvard Institute for International Development.

Melmed-Sanjak, J., Bloch, P. \& Hanson R. (1998). Project for the analysis of land tenure and agricultural productivity in the Republic of Macedonia. Working paper, no. 19, Land Tenure Center, University of Wisconsin-Madison. Dev. Econ. 3(2):225-275.

Monchuk,D.,Deininger,K.,Bank,W.,andAnand,R.M.(2010).DoesLandFragmentationReduceEfficiency: MicroEvidencefromIndia. In Agricultural \& Applied Economics Associations 2010 AAEA, CAES \& WAEA Joint Annual Meeting, Denver, Colorado July 25-27, number April 2016.

Najafi, M. R. (2003) “Watershed Modeling of Rainfall Excess Transformation into Run-off”. Journal of Hydrology, 270:273-281.

National Population Commission. (2006): Nigerian Census Report.

Nyagba J.L (1995 A)."The Geography of Benue State. In Benue State, the Land of Great Potentials. A Compendium, D.I Denga, edu., PP 84-96 (Calabar, Nigeria: Rapid Educational).

Nyagba J.L (1995 B). "Soil and Agriculture in Benue State. In Benue State, the Land of Great Potentials. A Compendium, D.I Denga, Edu., PP 134-149 (Calabar, Nigeria: Rapid Educational).

Sabates-Wheeler R. (2002) "Consolidation initiatives after Land Reform: responses to multiple dimensions of Land Fragmentation in European Agriculture". Journal of International Development, 14, 1055-1018

Sauer, J., Davidova, S., and Gorton, M. (2012). Land fragmentation, market integration and farm efficiency: empirical evidence from Kosovo. In The Development of an Integrated Planning and Decision Support System (IPDSS) for Land Consolidation the 86th Annual Conference of the Agricultural Economics Society, page 23.

Sundqvist P, Andersson L (2006). A study of the impacts of land fragmentation on agricultural productivity in Northern Vietnam. Bachelor Thesis. Department of Economics. Uppsala University.

Tan, S., Heerink, N., Qu, F., (2006). Land fragmentation and its driving forces in China. Land Use Policy, 23, 272285.

Tan. S. Heerink, N. Kuyvenhoven, A., \& Qu, F. (2010). Impact of land fragmentation on rice producer's technical efficiency in South-East China. NJAS-Wageningen Journal of Life Sciences, 57, 117-123. https://doi.org/10.1016/j.njas.2010.02.001

Thapa, S. (2007). The relationship between farm size and productivity: empirical evidence from the Nepalese midhills. CIFREM, Faculty of Economics, University of Trento

The World Bank (2005). Land Consolidation Issues in Northern Vietnam - Institutions, Implementation, Impacts. Working Paper, The World Bank.

Thomas J. (2006). Property rights, land fragmentation and the emerging structure of agriculture in Central and Eastern European countries. Elect. J. Agric. Dev. Econ. 3(2):225-275.

Van Dijk, T. (2003). Dealing with Central European land fragmentation: a critical assessment on the use of Western European instruments. Delft: Eburon.

Van Hung, P., MacAulay, G., Marsh, S., (2007). The economics of land fragmentation in the North Vietnam. The Australian Journal of Agricultural and Resource Economics, 51, 195-211.

Wan, G. H. and Cheng, E. (2010). Effects of land fragmentation and returns to scale in the Chinese farming sector. Applied Economics, 33(2):37-41. 